\title{
Health Risk Assessment of Nitrate Exposure in Well Water of Residents in Intensive Agriculture Area
}

\author{
Noraziah Jamaludin, Shaharuddin Mohd Sham \\ and Sharifah Norkhadijah Syed Ismail \\ Department of Environmental and Occupational Health, \\ Faculty of Medicine and Health Sciences, Universiti Putra Malaysia, 43400 UPM Serdang, Selangor, Malaysia
}

Received 2012-11-22, Revised 2013-05-20; Accepted 2013-05-21

\begin{abstract}
Nitrate in well water has become a public health concern especially in agriculture areas. Nitrate contamination in drinking water poses health risks to humans. This cross-sectional study was conducted with an aim to determine the health risk of residents in intensive agriculture area of Bachok Kelantan from nitrate exposure in drinking well water. Nitrate in well water was determined with Spectrophotometer while the health risk was determined through calculation of Chronic Daily Intake (CDI) and Hazard Index (HI). Results indicate that nitrate level in this study was below the Maximum Concentration Limit of National Drinking Water Quality Standard of Malaysia (NDWQS) $\left(<10 \mathrm{mg} \mathrm{L}^{-1}\right)$ with the Mean $\pm \mathrm{SD}$ of $1.66 \pm 2.11 \mathrm{mg} \mathrm{L}^{-1}$ and range between 0 to $9.60 \mathrm{mg} \mathrm{L}^{-1}$. The highest Mean $\pm \mathrm{SD}$ of nitrate was determined in Kampung Aman (3.34 \pm 4.07 $\mathrm{mg} \mathrm{L}^{-1}$ ). The mean $\pm \mathrm{SD}$ for CDI was $0.051 \pm 0.086 \mathrm{mg} \mathrm{kg} \mathrm{day}^{-1}$ and the HI was $<1$. This indicate the health risk of residents from nitrate exposure in this area were in acceptable range.
\end{abstract}

Keywords: Nitrate, Well Water, Intensive Agriculture Area, Health Hazard, Bachok Kelantan

\section{INTRODUCTION}

Groundwater is an important water resource located beneath the ground's surface in the soil pore spaces of fractured rock formations. Malaysia has approximately 5,000 billion $\mathrm{m}^{3}$ of groundwater storage with the volume of groundwater recharge approximately 120 billion $\mathrm{m}^{3}$ (Azuhan, 1999). The total yield of groundwater $(552,000$ $\mathrm{m}^{3}$ day $^{-1}$ ) is approximately $10 \%$ of the present water supply in the country. Groundwater mainly utilised for domestic purposes in confined to rural areas such as in Kelantan $\left(100,000 \mathrm{~m}^{3}\right.$ day $\left.^{-1}\right)$, Terengganu $\left(16,000 \mathrm{~m}^{3}\right.$ day $\left.^{-1}\right)$ and Perlis $\left(6,000 \mathrm{~m}^{3}\right.$ day $\left.^{-1}\right)$. It also utilised for industrial activities $(10 \%)$ and agricultural purposes $(5 \%)$ in states such as Selangor (Heng, 2004).

Nitrate in well water accumulating from both natural (i.e., soil mineralization and atmospheric deposition of nitrogen) and anthropogenic sources (i.e., industrial residue, intensive agriculture and septic tanks). Nevertheless, the heavy used of nitrogenous fertilizers in agriculture activities were the largest contribution of nitrate in well water (Ismail and Hashim, 2004; Mahvi et al., 2005; Tirado, 2007; Suthar et al., 2009; Zawawi et al., 2010).

Agriculture has become an important sector to Malaysian economy, in which there has been substantial development in the cultivation of rubber, oil palm, cocoa, fruits and vegetables. This has resulted in increasing usage of nitrogenous fertilizers (Kamil et al., 1990). For example, high levels of nitrogenous fertilizers were used in tobacco and rice agro systems in Kelantan contribute to high nitrate level in drinking well especially during the months of fertilizer application (Aminuddin et al., 1996). In other study,

Corresponding Author: Sharifah Norkhadijah Syed Ismail, Department of Environmental and Occupational Health, Faculty of Medicine and Health Sciences, Universiti Putra Malaysia, 43400 UPM Serdang, Selangor, Malaysia 
nitrate was determined lower than the threshold value for drinking water standard in most of the domestic wells in Malaysia. However, nitrate was more affected the well water rather than phosphate in which related to agricultural activities and animal farming (Khan et al., 2007). The monsoon and rainy season in the country have induced the leaching of this contaminant into well water.

Nitrate poses health risks to humans. It can cause 'blue baby syndrome' or methaemoglobinemia among infant (ATSDR, 2011). Methaemoglobinemia disease affects the blood cells' ability to carry oxygen to the body. Nitrate also can cause gastrointestinal illness, multiple digestive tract impairment, indigestion and inflammation of the stomach, gastroenteritis, abdominal pain, diarrhea and blood in the urine and faeces (Suthar et al., 2009; Moore et al., 2011). In addition, low level exposure to nitrate over many years, possibly could cause certain types of cancer such as digestive system cancer, stomach, esophagus, lungs, colon, bladder, ovaries, testicles, urogenital tract and non-Hodgkins lymphoma (Moore et al., 2011; Weyer et al., 2001).

This study was aimed to determine the nitrate levels in the drinking well and measure the health risk of exposed population in intensive agriculture area. Owing to the fact that intensive agriculture area used high volume of nitrogenous fertilizers-that this practice possibly leached high concentration of nitrate in well water, the population whom depending on groundwater as their water supply may get directly exposed to nitrate. This poses negative effect to their health.

In a context of this study, an intensive agriculture area in Bachok Kelantan, located at the North East of Peninsular Malaysia was selected as the study area. The population was highly depending on well water for domestic used as they were limited piped water supply in that area and the quality of well water were not being tested. Our initial hypothesis is that the nitrate level is within an acceptable standard limit and the health risks of population exposed are within acceptable range. This study provides a ground information on nitrate contamination in well water resulted from intensive fertilizer application. This is useful information for future work planning and important to predict the possible health outcome from nitrate exposure.

\section{MATERIALS AND METHODS}

\subsection{Description of Study Area}

Three villages in Bachok Kelantan (intensive agriculture area) were involved in this study namely as; Kampung Kandis, Kampung Telong and Kampung Aman (Fig. 1). Residents of these villages are depending on groundwater for their daily use. High usage of nitrogenous fertilizer in these areas may cause high risk of nitrate residue leach down into the well water.

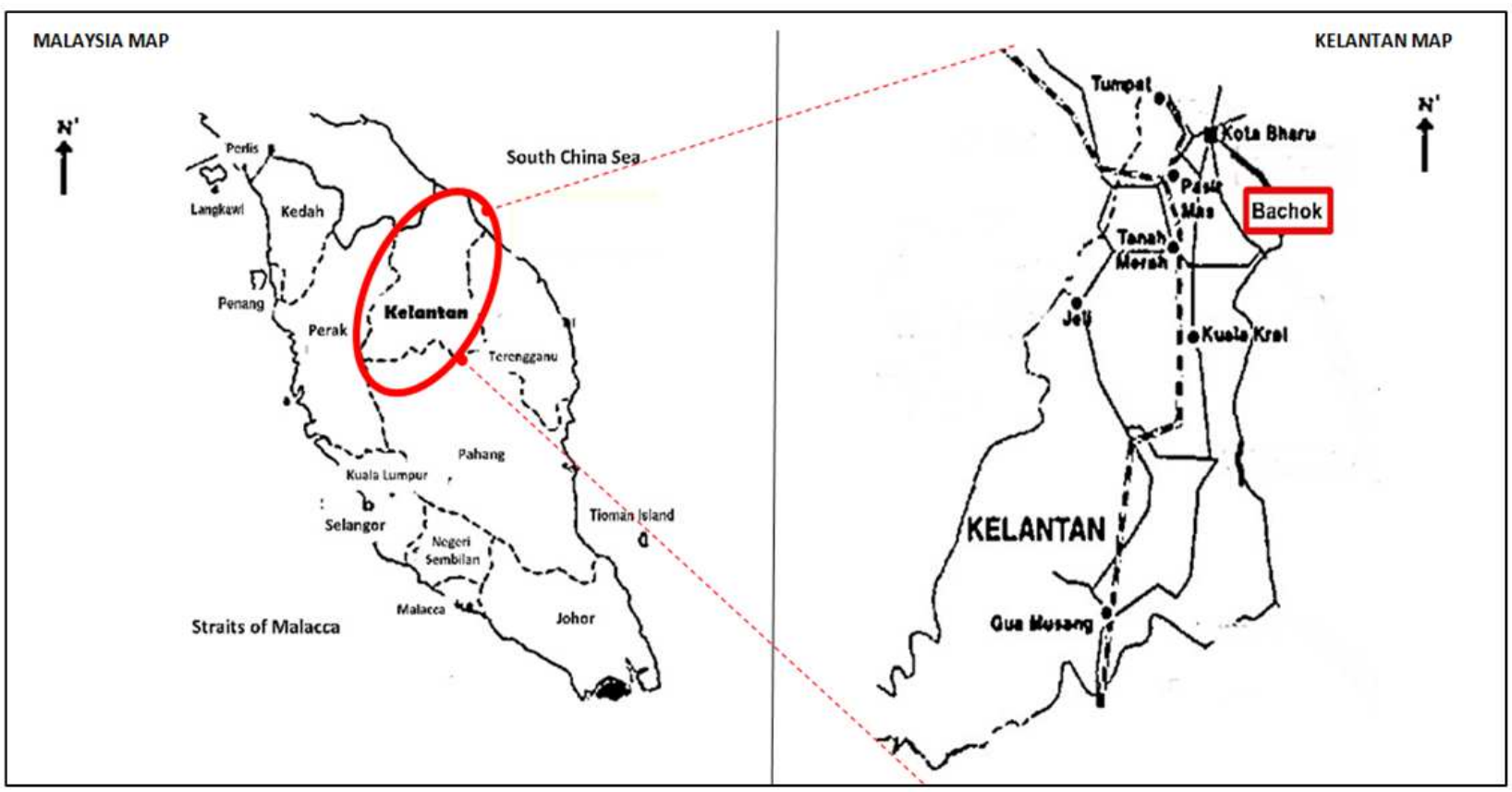

Fig. 1. Study area of Bachok, Kelantan 
Respondents aged 18 and above, in the study area were selected through purposively sampling method based on inclusion and exclusion criteria. The inclusion criteria were respondents aged 18 and above, long life residents in the selected area and used well water for drinking, while the exclusion criteria were respondents who used other than well water as drinking water and those who used filtered water system.

A set of questionnaire adapted from the Baseline, Descriptive and Time Activity used in the National Human Exposure Assessment Survey (NHEXAS) (Qaiyum et al., 2010) were administered to each respondent. These questionnaires collect information of socio demographic of respondents, the duration of residence and daily intake of drinking water.

\subsection{Well Water Sampling and Analysis}

The well water samples were collected directly from seventy (70) drinking wells and poured into $250 \mathrm{~mL}$ of High-Density Polyethylene (HDPE) bottle. Samples were stored in an ice-box and analyzed immediately within 24 to $48 \mathrm{~h}$. The analysis of sample was carried out using a Cadmium Reduction Method (Method 8171) with a HACH brand of DR/2500 spectrophotometer.

\subsection{Geographical Information System (GIS) and Statistical Analyses}

A Geographical Information System (GIS) was used in this study to determine the patterns and distributions of nitrate level in drinking water at the study area in a form of maps. Statistical analyses were performed using SPSS (version 17.0). Descriptive statistics and KruskalWallis test were used to compare the nitrate level in well water between villages.

\subsection{Health Risk Assessment}

Chronic Daily Intake (CDI) was used to calculate the health risk associated with nitrate exposure in well water, using the following Equation (1):

$$
\mathrm{CDI}=\frac{\mathrm{C} \times \mathrm{DI}}{\mathrm{BW}}
$$

where, CDI is Chronic Daily Intake ( $\mathrm{mg} / \mathrm{kg} / \mathrm{day}), \mathrm{C}$ is nitrate level in groundwater $(\mathrm{mg} / \mathrm{L}), \mathrm{DI}$ is an average daily intake rate of water (L/day) and BW is body weight $(\mathrm{kg})$.

For non-carcinogenic health effects posed by nitrate in drinking water, the Hazard Index (HI) was calculated using the following Equation (2):

$$
\mathrm{HI}=\frac{\mathrm{CDI}}{\mathrm{RfD}}
$$

where, CDI is for Chronic Daily Intake ( $\mathrm{mg} / \mathrm{kg} /$ day) and $\mathrm{Rfd}$ is reference dose $(\mathrm{mg} / \mathrm{kg} /$ day). RfD for this study was $1.6 \mathrm{mg} \mathrm{kg} \mathrm{day}^{-1}$ (USEPA, 2013). A HI value more than $1(\mathrm{HI}>1)$ shows a significant risk level. The higher the value, the greater the likelihood of adverse noncarcinogenic health effect.

\section{RESULTS}

\subsection{Socio-Demographic Information}

Seventy (70) respondents involved in this study are Malays from three villages of Kampung Kandis (31 respondents), Kampung Telong (31 respondents) and Kampung Aman (8 respondents). Forty-five (45) of them are female. Respondents were aged between 21-90 years old. Majority of respondents never have formal education (17 respondents) and most of them are farmers (31 respondents). The monthly income for most of the respondents was range between RM 500 to RM 1000 (32 respondents). Majority of them have lived in the area for more than 20 years (47 respondents) (Table 1).

Table 2 shows the well background in this study. All respondents in the study area used pump well and majority of the well were aged more than 15 years.

\subsection{Nitrate Level in Well Water}

The Mean \pm SD of nitrate level in well water of this study was $1.66 \pm 2.11 \mathrm{mg} \mathrm{L}^{-1}$ and range between $0-9.60$ mg L ${ }^{-1}$ (Table 3). Kruskal-Wallis test was used to compare nitrate levels between villages. There was no significant difference of nitrate level between villages ( $p$ $=0.749)$. The highest Mean \pm SD of nitrate level was detected in Kampung Aman (3.34 $\left.\pm 4.07 \mathrm{mg} \mathrm{L}^{-1}\right)$ followed by Kampung Kandis $\left(1.45 \pm 1.32 \mathrm{mg} \mathrm{L}^{-1}\right)$ and Kampung Telong $\left(1.43 \pm 1.95 \mathrm{mg} \mathrm{L}^{-1}\right)$.

Figure 2 illustrate the nitrate level with Inverse Distance Weight (IDW) interpolation technique with GIS. High level of nitrate was detected at Kampung Aman located at the South of the study area.

\subsection{Comparison of Nitrate Level with the National Standard}

According to Malaysian National Drinking Water Quality Standard (NDWQS), the Maximum Concentration Limit for nitrate is $10 \mathrm{mg} \mathrm{L}^{-1}(\mathrm{MOH}$, 2012). Figure 3 indicates that nitrate level in all wells in this study were within the acceptable value limit $(<10$ $\mathrm{mg} \mathrm{L}^{-1}$ ), except for three wells in Kampung Aman, that almost reach the standard limit. 
Noraziah Jamaludin et al. / American Journal of Applied Sciences, 10 (5): 442-448, 2013<smiles>[Y]C1CC(N)C(F)C1S</smiles>

Legend

- Respondent house Nitrate concentration $(\mathrm{mg} / \mathrm{L})$

High: 9.6

Low: 0.0008

$\begin{array}{llll}750 & 375 & 0 & 750\end{array}$ Meters

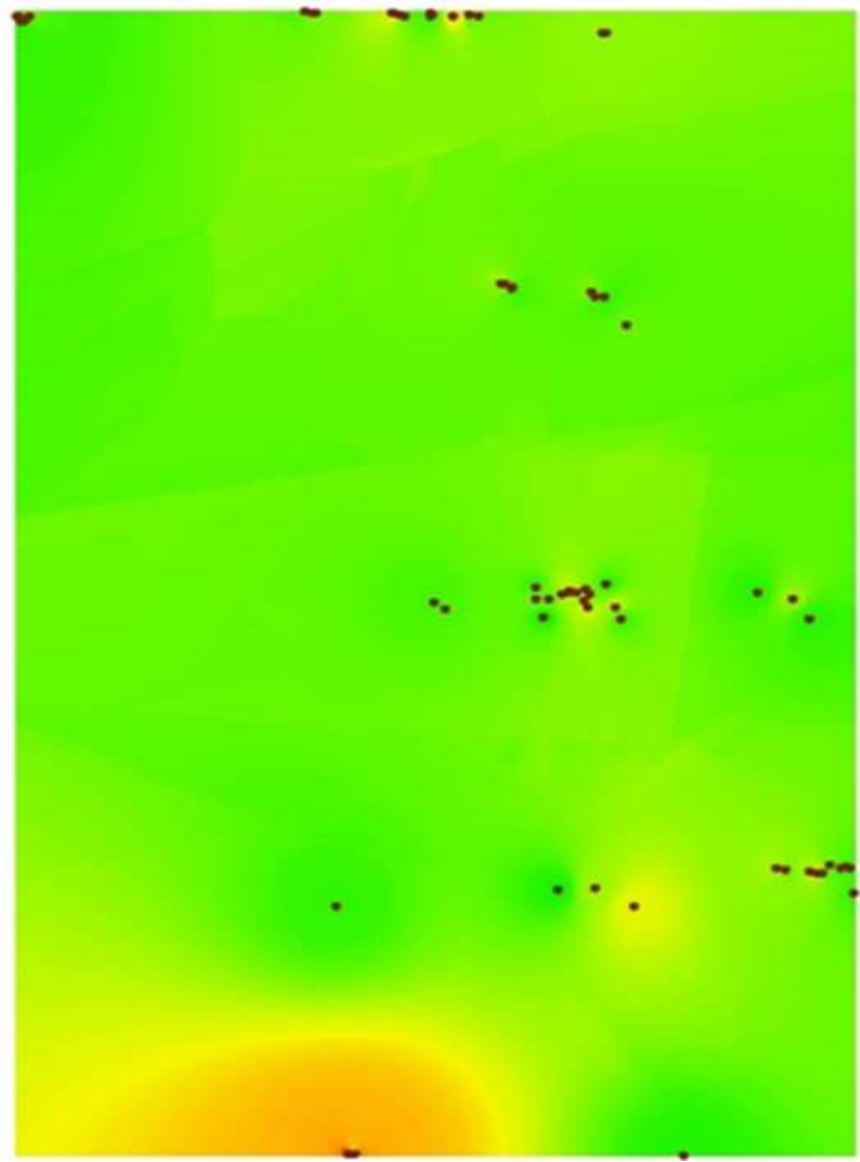

Fig. 2. The distribution of nitrate concentration

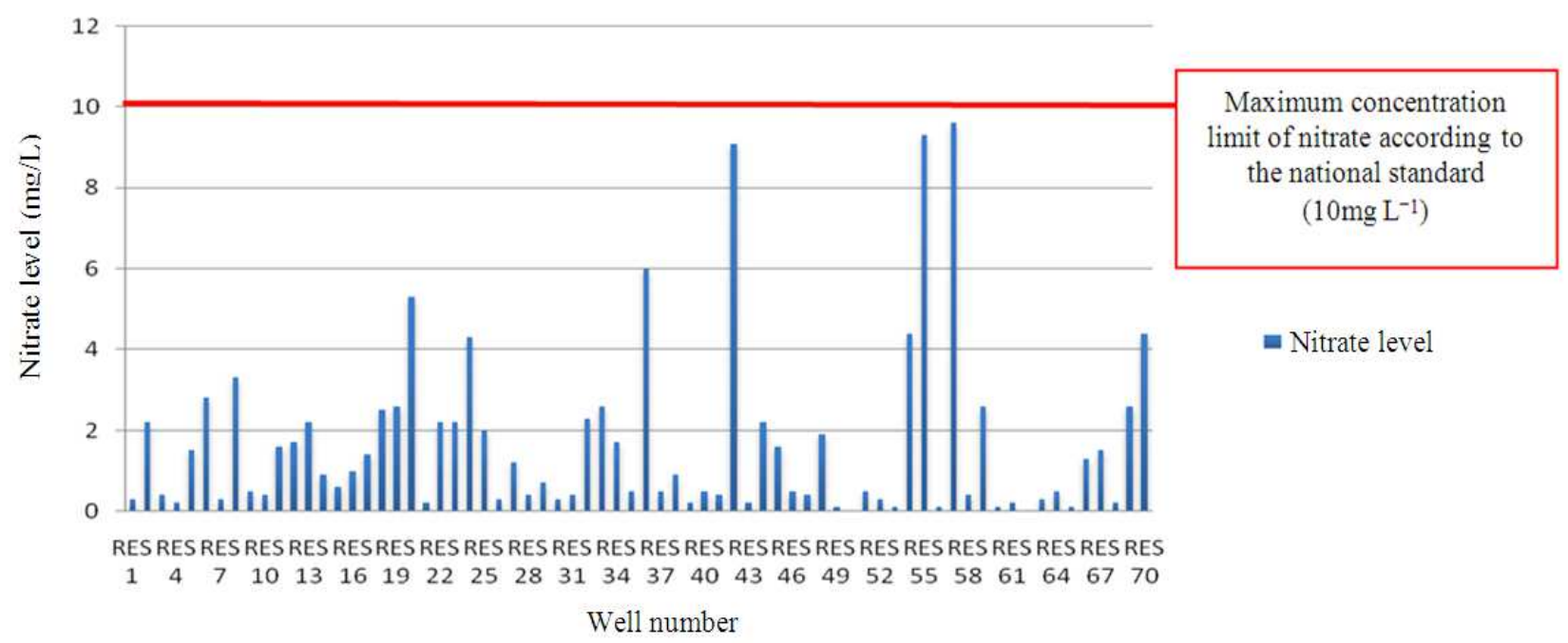

Fig. 3. Comparison of nitrate level with National standard 
Table 1. Socio-demographic information

\begin{tabular}{lrr}
\hline Variable & No. of respondent & $(\%)$ \\
\hline Gender: & 25 & \\
Male & 45 & 65.7 \\
Female & & \\
Age: & 6 & 8.6 \\
$<25$ & 12 & 17.1 \\
$25-35$ & 16 & 22.9 \\
$36-45$ & 15 & 21.4 \\
$46-55$ & 21 & 30.0 \\
>55 & & \\
Education Level: & 17 & 24.3 \\
No education & 15 & 21.4 \\
Primary school & 15 & 21.4 \\
PMR & 15 & 21.4 \\
SPM & 5 & 7.1 \\
STPM & 3 & 4.3 \\
Higher Education & & \\
Income (RM): & 31 & 44.3 \\
<500 & 32 & 45.7 \\
$500-1000$ & 5 & 1.1 \\
1001-1500 & 1 & 1.4 \\
1501-2000 & 1 & 8.6 \\
>2000 & & 14.3 \\
Period of residency: & 6 & 10.0 \\
< 1 year & 7 & 67.1 \\
1-10 years & 47 & \\
11-20 years & & \\
> 20 years & & \\
\hline N = 70 & &
\end{tabular}

Table 2. Well information

\begin{tabular}{lcr}
\hline Variable & No. of respondents & $(\%)$ \\
\hline Age of well: & & \\
<1 year & 7 & 10.0 \\
1-5 years & 4 & 5.7 \\
6-10 years & 3 & 4.3 \\
11-15 years & 7 & 10.0 \\
>15 years & 49 & 70.0 \\
\hline
\end{tabular}

$\mathrm{N}=70$

Table 3. Nitrate level in well water between villages

\begin{tabular}{lllll}
\hline Village & $\begin{array}{l}\text { No. of } \\
\text { well }\end{array}$ & $\begin{array}{l}\text { Mean } \pm \\
\text { SD }(\mathrm{mg} / \mathrm{L})\end{array}$ & $\begin{array}{l}\text { Range } \\
(\mathrm{mg} / \mathrm{L})\end{array}$ & P-value \\
\hline Kg. Kandis & 31 & $1.45 \pm 1.32$ & $0.00-5.30$ & \\
Kg. Telong & 31 & $1.43 \pm 1.95$ & $0.00-9.10$ & 0.749 \\
Kg. Aman & 8 & $3.34 \pm 4.07$ & $0.10-9.60$ & \\
\hline
\end{tabular}

$\mathrm{N}=70$

Table 4. Chronic daily intake (CDI) estimation

\begin{tabular}{|c|c|c|c|c|c|}
\hline & $\begin{array}{l}\text { Nitrate con- } \\
\text { centration } \\
(\mathrm{mg} / \mathrm{L})\end{array}$ & $\begin{array}{l}\text { *DI } \\
\text { (L/day) }\end{array}$ & $* \mathrm{~W}(\mathrm{~kg})$ & $\begin{array}{l}{ }^{*} \mathrm{CDI}(\mathrm{mg} \\
/ \mathrm{kg} / \text { day })\end{array}$ & $\begin{array}{l}\text { Hazard Index } \\
\text { (HI) value }\end{array}$ \\
\hline Mean & 1.66 & 1.80 & 59.95 & 0.051 & 0.032 \\
\hline SD & 2.11 & 0.87 & 10.47 & 0.086 & 0.054 \\
\hline Range & $0.00-9.60$ & $0.5-4.5$ & $36-81$ & $0.00-0.48$ & $0.00-0.3$ \\
\hline
\end{tabular}

\subsection{Health Risk Assessment}

The health risk exposure of nitrate was calculated as Chronic Daily Intake (CDI) and Hazard Index (HI) in this study. The Mean \pm SD for CDI was $0.051 \pm 0.086 \mathrm{mg}$ $\mathrm{kg}$ day $^{-1}$, with the average body weight of $60 \mathrm{~kg}$ and daily water intake of $1.80 \mathrm{~L}^{-1 a y}{ }^{-1}$ (Table 4). Hazard Index (HI) was calculated by dividing the CDI value with the Reference Dose (RfD). The Reference Dose (RfD) for nitrate is $1.6 \mathrm{mg} \mathrm{kg}{ }^{-1}$ (USEPA, 2013). HI value greater than 1 indicated a potential for an adverse health effect to occur (NJEDP, 2007). The HI values for all respondents in this study were less than 1 , with the Mean \pm SD was $0.032 \pm 0.054$.

\section{DISCUSSION}

The mean \pm S.D of nitrate in this study $(1.66 \pm 2.11$ $\mathrm{mg} \mathrm{L}^{-1}$ ) was considered as in normal value. According to Schmoll (2006), the normal concentration of nitrate in surface water or groundwater is between 0 to $18 \mathrm{mg} \mathrm{L}^{-1}$. However, nitrate can reach high levels as a result from agricultural run-off, refuse dump run-off, or contamination of human and animal wastes. Study by Shams et al. (2009) indicated the mean of nitrate level in drinking water networks in Tabas, Iran was range between 2.9 to $3.25 \mathrm{mg} \mathrm{L}{ }^{-1}$-slightly higher than this study. Although the average value of nitrate in Kampung Aman (this study) was reported as high $(3.34 \pm 4.07 \mathrm{mg}$ $\left.\mathrm{L}^{-1}\right)$, but the value was still within the average reported in other region of the world. For example, nitrate level in Sumas-Blaine aquifer, USA for the period of 1990 to 2000 showed a mean value of $5.7 \mathrm{mg} \mathrm{L}^{-1}$ (Almasri and Kaluarachchi, 2004). CCME (2007) also reported that nitrate concentration in groundwater often exceeding the Canadian Drinking Water Quality of $10 \mathrm{mg} \mathrm{L}^{-1}$.

Low level of nitrate determined in this study was probably influenced by the rainfall event; as sampling was conducted after rainy season in January 2012. According to CCME (2007), rainfall influenced the concentration of Nitrate, as it entering the groundwater at high rate at the beginning of rainy season, decrease throughout the rainy season and remain at constant low level during dry season. During the rainy season, water table rises and nitrate in unsaturated zone (such as soil) becomes mobilized into groundwater. Therefore, nitrate level is high at this condition. In contrast, Nitrate will accumulate in soil during dry season, decrease of mobilization into stream and groundwater, thus resulted to lower Nitrate concentration in the groundwater. 
Another factor that caused low Nitrate level in this study was due to sampling time. Sample was collected during pre-fertilization period, where applications of fertilizer to the crops not yet started and no excessive fertilizer leaching to groundwater. Nitrate concentration in well water was also depending on crop system. Peng et al. (2012) indicated that different cropping system caused different concentration of nitrate in groundwater. The continuous crop system increased the tendency for nitrate to leach downwards compared to mixed crop system. Farmers in this study practiced mixed crop system that caused low concentration of nitrate.

\subsection{Comparison of Nitrate Levels Between Villages and to the National Standard}

The highest nitrate level (Mean \pm SD) was detected in Kampung Aman $\left(3.34 \pm 4.07 \mathrm{mg} \mathrm{L}^{-1}\right)$. Only three wells in Kampung Aman have high nitrate concentration (9.6 $\mathrm{mg} \mathrm{L}^{-1}$ ) that almost exceeded the standard limit. High concentration of nitrate in these areas was possibly related to the bedrock sources within the aquifer and also influenced by hydrological factors such as the hydrological mixing processes, frequency of rainfall and duration of rainfall (Grover, 2006).

Nitrate concentration in well water of the study area were below the Maximum Allowable Limit Malaysian National Drinking Water Quality Standard (NDWQS) and the International standard of USEPA $\left(10 \mathrm{mg} \mathrm{L}^{-1}\right)$. In most countries, nitrate levels in drinking water normally not exceeded $10 \mathrm{mg} \mathrm{L}^{-1}$. However, in some areas, the concentrations can be high as a result of agriculture activities, discharge of sewage effluent and certain industrial wastes (WHO, 2011).

The uptake of nitrate as nutrient by crops is responsible for the nitrate level in water source. Low concentration of nitrate possibly due to nitrate fertilizer application to crops was insufficient, in which reduce the leaching of excess nitrate into water streams or aquifers. Many studies showed nitrate level in groundwater increase when increase the water table during raining season. While, during post-raining or during dry and warm weather, nitrate level seems to decrease (Rajmohan and Elango, 2005; Almasri and Kaluarachchi, 2004). Shams et al. (2009) indicated that weather conditions should be considered as it may influence the concentration of chemical in water source.

Previous study in Kelantan, also indicated nitrate contamination was found to be prominent and persistent in groundwater. In average, $15 \%$ of well water samples were found to have nitrate concentrations above the maximum acceptable level of $10 \mathrm{mg} \mathrm{L}^{-1}$ with the highest concentration was $30 \mathrm{mg} \mathrm{L}^{-1}$ (Aminuddin et al., 1996).

\subsection{Exposure and Health Risk Assessment}

Hazard Index (HI) values for all respondents in this study were less than 1 and this indicate the risk of adverse effect of nitrate pollution in groundwater in respective areas was acceptable.

\section{CONCLUSION}

This study has indicated that nitrate concentration in well water of Kampung Aman, Telong and Kandis in Bachok Kelantan are within the acceptable limit and the health risk of respondents in these area were considered as low. Although nitrate level was low in this study, but effort to minimize any further exposure of nitrate towards human as well as ecosystem and environment should be put as vital concern.

A monitoring programme and health education should be in place in areas where drinking water has a high probability of nitrate contamination such as at agricultural areas. Wells are also required to be regularly tested to ensure that the water being supplied for public meets the drinking water standards. Use of water filter system should be recommended in order to minimize contamination. In addition, wells must be drilled deep enough to extend past the water table into the groundwater aquifer below as nitrate concentration in the well water will decrease as the depth of well increase.

\section{ACKNOWLEDGEMENT}

Sincere gratitude to the laboratory and academic staff of Department Environmental and Occupational Health, Faculty of Medicine and Health Sciences, University Putra Malaysia for their continuing support. Last but not least, thanks to all respondents involved in this study.

\section{REFERENCES}

Almasri, M.N. and J.J. Kaluarachchi, 2004. Assessment and management of long-term nitrate pollution of ground water in agriculture-dominated watersheds. J. Hydrol., 295: 225-245. DOI: 10.1016/j.jhydrol.2004.03.013 
Aminuddin, B.Y., Sharma, M.L. and Willett, I.R. 1996. Agricultural impacts on ground water quality. Proceedings of an International Workshop Held in Kola Bharu, Oct. 24-27, Kelantan, Malaysia.

ATSDR, 2011. The priority list of hazardous substances that will be the subject of toxicological profiles. Agency for Toxic Substances and Disease Registry.

Azuhan, M., 1999. Malaysian Groundwater in the Next Millenium. Proceedings of the Grundfos Dealers' Conference, (GDC' 99), Shah Alam Community Water Center's Health and Drinking Water Series.

CCME, 2007. Canadian water quality guidelines for the protection of aquatic life. Canadian Council of Ministers of the Environment.

Grover, V.I., 2006. Water: Global Common and Global Problems. 1st Edn., Science Publishers, Enfield, ISBN-10:1578084091, pp: 533.

Heng, C.L., 2004. Groundwater utilisation and management in Malaysia. Proceedings of $41 \mathrm{st}$ Coorinating Committee for Geoscience Programmes in East an Southeast Asia (CCOP) Annual Session. Nov. 15-18.

Ismail, W.R. and K.A.K. Hashim, 2004. Longitudinal variation of water quality in Sungai Jarum catchment-linking ecology with hydrology for reservoir management. Malays. J. Environ. Manage., 5: 45-54.

Kamil, M.Y., W.S. Norazmin and S. Zainudin, 1990. A general survey of nitrate-nitrogen levels in wellwater under different landuses. Pertanika, 13: 79-83.

Khan, I., H. Ullah and M. Imran, 2007. Nitrate and phosphate pollution in surface and ground water in Western Malaysia. J. Chem. Soc. Pak., 29: 315-320.

Mahvi, A.H., J. Nouri, A.A. Babei and R. Nabizadeh, 2005. Agricultural activities impact on groundwater nitrate pollution. Int. J. Environ. Sci. Tech., 2: 41-47.

$\mathrm{MOH}, 2012$. Borang soal selidik komuniti kementerian kesihatan Malaysia. Strategic Plan Inform. Technol., 2: 2011-2015.

Moore, E., E. Matalon, J. Clary, L. Firestone and S.D. Anda, 2011. The Human Costs of Nitratecontaminated Drinking Water in the San Joaquin Valley. 1st Edn., Pacific Institute for Studies in Development, Oakland, ISBN-10: 1893790312, pp: 45.

NJEDP, 2007. Risk screening policy and second-level risk screening. New Jersey Department of Environmental Protection.
Peng, L., Z. Cheng-Jun, Z. Tong-Ke, L. Bao-Cun and L. Xin-Rong et al., 2012. The variance of nitrate nitrogen in groundwater of intensive agricultural region in Daxing District from 2005 to 2011. Proceedings of the International Conference on Biomedical Engineering and Biotechnology, May 28-30, IEEE Xplore Press, Macau, pp: 1854-1857. DOI: 10.1109/iCBEB.2012.448

Qaiyum, M.S., M.S. Shaharudin, A.I. Syazwan and A. Muhaimin, 2010. Health risk assessment after exposure to aluminium in drinking water between two different villages. J. Water Resource Protect., 3: 268-274. DOI: 10.4236/jwarp.2011.34034

Rajmohan, N. and L. Elango, 2005. Nutrient chemistry of groundwater in an intensively irrigated region of southern India. Environ. Geol., 47: 820-830. DOI: 10.1007/s00254-004-1212-z

Schmoll, O., 2006. Protecting Groundwater for Health: Managing the Quality of Drinking Water Sources. 1st Edn., IWA Publishing, London, ISBN-10: 1843390795, pp: 678.

Shams, M., R.N. Nodehi, M. Alimohammadi A.H. Mahvi, 2009. A survey of nitrate and fluoride in water distribution networks of tabas, Iran. World Applied Sci. J., 7: 1516-1520.

Suthar, S., P. Bishnoi, S. Singh, P.K. Mutiyar and A.K. Nema et al., 2009. Nitrate contamination in groundwater of some rural areas of Rajasthan, India. J. Hazard. Mater., 171: 189-199. DOI: 10.1016/j.jhazmat.2009.05.111

Tirado, R., 2007. Nitrates in drinking water in the Philippines and Thailand. Greenpeace Research Laboratories.

USEPA, 2013. Integrated Risk Information System (IRIS). United States Environment Protection Agency.

Weyer, P.J., J.R. Cerhan, B.C. Kross, G.R. Hallberg and J. Kantamneni et al., 2001. Municipal drinking water nitrate level and cancer risk in older women: The Iowa women's health study. Epidemiology, 12: 327-38. PMID: 11338313

WHO, 2011. Nitrate and nitrite in drinking-water: background document for development of WHO Guidelines for Drinking-water Quality. World Health Organization.

Zawawi, M.A.M., M.K. Yusoff, H. Hussain and S. Nasir, 2010. Nitrate-nitrogen concentration variation in groundwater flow in a paddy field. Inst. Eng., Malaysia, 71: 1-10. 